\title{
APLIKASI LIMBAH KULIT BUAH KAKAO SEBAGAI MEDIA FERMENTASI ASAM LAKTAT UNTUK BAHAN BAKU BIOPLASTIK
}

\section{(APPLICATION OF COCOA POD HUSK WASTE AS A MEDIUM FOR LACTIC ACID FERMENTATION FOR RAW MATERIALS OF BIOPLASTIC)}

\author{
Rambat $^{1,2^{*}}$, Nurul Hidayat Aprilita ${ }^{1}$, dan Bambang Rusdiarso ${ }^{1}$, \\ ${ }^{1}$ Departemen Kimia, Universitas Gadjah Mada, Yogyakarta \\ ${ }^{2}$ Balai Besar Kulit, Karet dan Plastik, Yogyakarta \\ E-mail : rambat80@yahoo.com
}

Received : 18 September 2015; revised : 28 September 2015; accepted : 30 September 2015

\begin{abstract}
ABSTRAK
Penelitian ini bertujuan untuk mempelajari kondisi optimum proses delignifikasi, hidrolisis asam dan enzimatis kulit buah kakao serta pemanfaatannya sebagai media fermentasi asam laktat. Karakterisasi kulit buah kakao dilakukan dengan metode X-Ray Diffraction (XRD), Spektrometri Infra Red(IR) dan Scanning Electron Microscopy(SEM). Konsentrasi glukosa ditentukan secara kuantitatif dengan metode UV-Sulfat, sedangkan total asam laktat dengan metode titrasi asam basa. Hasil penelitian menunjukkan bahwa konsentrasi optimum $\mathrm{NaOH}$ pada delignifikasi kulit buah kakao adalah 6\%, sedangkan kondisi optimum hidrolisis asam adalah konsentrasi $\mathrm{H}_{2} \mathrm{SO}_{4} 2,0 \%$, suhu $120^{\circ} \mathrm{C}$ dan waktu 30 menit. Hasil karakterisasi menunjukkan bahwa proses ini hanya dapat menghidrolisis hemiselulosa dan selulosa amorf. Glukosa hasil hidrolisis asam dapat digunakan sebagai media fermentasi dan menghasilkan asam laktat sebesar $13,27 \mathrm{~g} / \mathrm{L}$.
\end{abstract}

Kata kunci : Kulit buah kakao, Delignifikasi, Hidrolisis, Fermentasi

\section{ABSTRACT}

This research aims to determine the optimum conditions for delignification, acid hydrolysis process of cocoa pod husk and its use as a medium for lactic acid fermentation. The characterization of the cocoa pod husk was conducted by using X-Ray Diffraction (XRD), Infra Red Spectrometry (IR) and Scanning Electron Microscopy (SEM). The glucose concentration was determined quantitatively by UV-sulfate method, while the lactic acid concentration by acid-base titration method. The results showed that the optimum $\mathrm{NaOH}$ concentration for cocoa pod husk delignification was $6 \%$, while the optimum conditions of acid hydrolysis process were $2.0 \% \mathrm{H}_{2} \mathrm{SO}_{4}$ concentration, temperature of $120^{\circ} \mathrm{C}$ and within 30 minutes. The result characterization showed that the process could hydrolyze hemicellulose and amorf cellulose only. Glucose resulted from acid hydrolysis could be used as a medium for lactic acid fermentation that produced $13.27 \mathrm{~g} / \mathrm{L}$ lactic acid.

Keywords : Cacao pod husk, Delignification, Hydrolysis, Fermentation

\section{PENDAHULUAN}

Indonesia merupakan negara penghasil kakao (Theobroma Cacao L.) terbesar ketiga setelah Pantai Gading dan Ghana. Produksi kakao di Indonesia pada tahun 2010/2011 mencapai 450.000 ton dan diperkirakan pada tahun 2011 sampai dengan 2012 produksi kakao Indonesia mencapai 500.000 ton. Pada tahun 2011, luas tanaman kakao di Indonesia mencapai 1.677.254 ha dengan produksi sebesar 712.231 ton dan didominasi oleh perkebunan rakyat $(94,5 \%)$ (Direktorat Jenderal
Perkebunan, 2011). Kulit buah kakao (Cocoa pod husk, $\mathrm{CPH}$ ) merupakan limbah dari pengolahan biji kakao. Pengolahan buah kakao menghasilkan sejumlah besar kulit buah kakao sebagai limbah (Alemawor et al. 2009). Berat kulit buah kakao berkisar antara antara (70\% sampai dengan 75$) \%$ dari berat buah utuh kakao, di mana setiap ton buah kakao akan menghasilkan $700 \mathrm{~kg}$ sampai dengan $750 \mathrm{~kg}$ kulit buah kakao (Cruz et al. 2012). Kulit buah kakao mengandung $74,0 \%$ holoselulosa, $35,4 \%$ 
selulosa, $37,0 \%$ hemiselulosa dan $14,7 \%$ lignin (Daud et al. 2013).

Limbah hasil panen dan pengolahan pertanian termasuk kulit atau cangkang buah kakao belum dimanfaatkan secara optimal. Kulit buah kakao telah diteliti dapat digunakan sebagai bahan pembuatan bioetanol (Pratiwi et al. 2010), bahan pembuatan karbon aktif (Cruz et al. 2012), pakan ternak (Puastuti dan Susanna 2014), bahan baku pembuatan Carboxymethyl Cellulose (CMC) (Nisa et al. 2014) dan bahan baku produk pangan (Wijaya 2014).

Asam laktat dapat dipolimerisasi menjadi polilactic acid untuk pembuatan plastik biodegradable yang digunakan untuk aplikasi medis (Hofvendahl dan Hägerdal 2000). Plastik biodegradable atau bioplastik bersifat dapat terdegradasi secara alami jika dibandingkan dengan plastik konvensional yang terbuat dari bahan baku petroleum. Asam laktat dapat dibuat melalui proses fermentasi maupun sintesis kimia. Fermentasi merupakan metoda yang paling banyak digunakan oleh industri. Bahan lignoselulosa dapat dimanfaatkan sebagai sumber bahan baku alternatif dalam pembuatan asam laktat dengan metode fermentasi. (Rahman 2013).

Tahapan utama konversi lignoselulosa menjadi asam laktat melalui proses fermentasi adalah 1) perlakuan awal untuk menghilangkan lignin, 2) hidrolisis untuk memecah polimer selulosa menjadi gula sederhana, 3) fermentasi oleh bakteri yang sesuai (Rahman 2011). Proses penghilangan lignin (dapat dilakukan secara fisikawi, kimiawi, dan biologis. Delignifikasi secara kimiawi dapat dilakukan dengan asam, alkali, dan reagen pelarut selulosa. (Rahman 2011). $\mathrm{NaOH}$ dapat memisahkan lignin tanpa merusak struktur selulosa dan dapat dilakukan pada temperatur ruang.

Penelitian ini bertujuan untuk mempelajari pengaruh variasi konsentasi basa $\mathrm{NaOH}$ pada proses delignifikasi limbah kulit buah kakao, menentukan kondisi optimum proses hidrolisis asam serta mempelajari penggunaan glukosa hasil hidrolisis sebagai media fermentasi asam laktat dengan bakteri Lactobacillus plantarum.

\section{BAHAN DAN METODE}

\section{Bahan}

Bahan-bahan yang digunakan dalam penelitian ini adalah: kulit buah kakao dari perkebunan rakyat di desa Tangkisan, Kecamatan Kokap, Kabupaten Kulonprogo, DIY. Indikator phenolpthalein, bahan kimia grade p.a. dari E. Merck antara lain: $\mathrm{NaOH}, \mathrm{H}_{2} \mathrm{SO}_{4}$, D- glukosa, $\quad \mathrm{CH}_{3} \mathrm{COONa} .3 \mathrm{H}_{2} \mathrm{O}, \quad \mathrm{MgSO}_{4} .7 \mathrm{H}_{2} \mathrm{O}$, $\mathrm{MnSO}_{4} .4 \mathrm{H}_{2} \mathrm{O}, \mathrm{K}_{2} \mathrm{HPO}_{4}$, Triamonium sitrat, asam oksalat. Isolat Lactobacillus plantarum dari Laboratorium Mikrobiologi PAU UGM. Bahan mikrobiologi dari Oxoid seperti: De Man Rogosa and Sharpe (MRS), sorbitan mono-oleate, peptone, lab-lemco powder dan yeast extract.

Alat-alat yang digunakan dalam penelitian ini adalah peralatan gelas, Oven Merk Memmert, Grinder, Sentrifuse Merk Beckman Model J-6B, Autoclave Merk Hirayama, Laminar, $\mathrm{pH}$ meter digital Merk Hanna 210, pH stick, Incubator Shaker, Neraca Analitik Merk Sartorius, Buret Digital, Spektrofotometer IR Shimadzu Model IR 8201 PC, Spektrofotometer UV-Visible UV1601PC, Difraktometer sinar-X Shimadzu PC 6000, Scanning Electron Microscopy (SEM) (Lab LPPT UGM).

\section{Metode}

\section{Preparasi Kulit Buah Kakao}

Kulit buah kakao matang yang masih basah dijemur di bawah sinar matahari hingga kadar air $\pm 14 \%$ kemudian digiling dengan menggunakan grinder dengan ayakan ukuran 100 mesh. Hasil yang diperoleh dikarakterisasi dengan spektrofotometer $I R$, difraktometer sinar$X$ dan Scanning Electron Microscopy dan diuji kadar selulosa, hemiselulosa dan lignin.

\section{Delignifikasi}

$\mathrm{NaOH}(2 \%, 4 \%, 6 \%, 8 \%$ dan $10 \%)$ digunakan untuk delignifikasi kulit buah kakao. Delignifikasi dilakukan pada suhu kamar selama 24 jam dengan perbandingan berat bubuk kulit buah kakao terhadap pelarut 1:15. Padatan hasil delignifikasi dilakukan uji kadar selulosa, hemiselulosa, lignin. Bubuk kulit buah kakao hasil delignifikasi optimum dikarakterisasi dengan menggunakan spektrofotometer IR dan difraktometer sinar-X.

\section{Hidrolisis Asam}

Setelah delignifikasi, padatan yang dihasilkan dihidrolisis dengan $\mathrm{H}_{2} \mathrm{SO}_{4} 0,5 \%(\mathrm{v} / \mathrm{v})$; $1,0 \%(\mathrm{v} / \mathrm{v}) ; 1,5 \%(\mathrm{v} / \mathrm{v}) ; 2,0 \%(\mathrm{v} / \mathrm{v})$ dan $2,5 \%(\mathrm{v} / \mathrm{v})$ serta perbandingan berat bubuk kulit buah kakao terhadap larutan 1:10. Temperatur hidrolisis bervariasi pada $105^{\circ} \mathrm{C}, 110^{\circ} \mathrm{C}, 115^{\circ} \mathrm{C}, 120^{\circ} \mathrm{C}$ dan $125^{\circ} \mathrm{C}$ dan waktu hidrolisis bervariasi selama 10 menit, 20 menit, 30 menit, 40 menit dan 50 menit. Larutan disaring, filtrat diuji dengan menggunakan spectrofotometer UVVisible dan padatan pada kondisi hidrolisis optimum diuji kadar selulosa, hemiselulosa, dan ligninnya serta dikarakterisasi dengan 
menggunakan spektrofotometer IR dan difraktometer sinar-X.

\section{Fermentasi Asam Laktat}

Proses fermentasi diawali dengan aktivasi bakteri Lactobacillus plantarum. Isolat bakteri Lactobacillus plantarum sebanyak $1 \mathrm{ml}$ dalam gliserol diinokulasikan dalam $10 \mathrm{~mL}$ medium MRS kemudian diinkubasi pada suhu $37^{\circ} \mathrm{C}$ selama 24 jam. Proses diulang sekali lagi untuk mengaktifkan bakteri. Starter dibuat dengan menginokulasikan $1 \mathrm{~mL}$ bakteri Lactobacillus plantarum dalam $10 \mathrm{~mL}$ media MRS dan diinkubasi pada suhu $37^{\circ} \mathrm{C}$ selama 16 jam.

Media produksi disiapkan dari glukosa hasil hidrolisis optimum dengan cara sebanyak $50 \mathrm{~mL}$ glukosa dinetralkan dengan larutan $\mathrm{NaOH}$ $0,1 \mathrm{~N}$ sampai $\mathrm{pH}$ 5. Pengaturan $\mathrm{pH}$ ini dimaksudkan untuk proses detoksifikasi larutan hasil hidrolisis asam. Larutan hasil hidrolisis asam pada $\mathrm{pH} 5$ ditambahkan dengan $4 \mathrm{~g} / \mathrm{L}$ yeast extract, $10 \mathrm{~g} / \mathrm{L}$ pepton, $8 \mathrm{~g} / \mathrm{L}$ lab-lemco powder, $5 \mathrm{~g} / \mathrm{L}$ sodium asetat, $1 \mathrm{ml} / \mathrm{L}$ tween 80,2 $\mathrm{g} / \mathrm{L}$ potasium fosfat, $2 \mathrm{~g} / \mathrm{L}$ diammonium hidrogen sitrat, 0,2 $\mathrm{g} / \mathrm{L}^{\mathrm{MgSO}_{4}}$ dan $0,05 \mathrm{~g} / \mathrm{L} \mathrm{MnSO}_{4}$. Larutan diaduk dengan pengaduk magnet sampai larut sempurna dan kemudian disterilisasi dalam autoclave pada suhu $121^{\circ} \mathrm{C}$ selama 15 menit. Fermentasi asam laktat dilakukan dengan menambahkan $0,5 \mathrm{~mL}$ starter Lacobacillus plantarum ke dalam $50 \mathrm{~mL}$ media produksi, kemudian diagitasi dalam Incubator Shaker dengan laju pengadukan $200 \mathrm{rpm}$ suhu $37^{\circ} \mathrm{C}$ selama 48 jam. Pengambilan sampel dilakukan pada jam ke-0 jam, 12 jam, 24 jam, 36 jam dan 48 jam.

\section{Metode analisis}

Analisis lignin selulosa dan hemiselulosa dilakukan dengan modifikasi metode Chesson. Penentuan kadar glukosa dilakukan dengan metode asam sulfat-UV (Albalasmeh et al. 2013). Metode ini menggunakan Spektrofotometer UV-Visible pada panjang gelombang $315 \mathrm{~nm}$. Pengujian kadar asam laktat dilakukan pada filtrat hasil fermentasi. Filtrat hasil fermentasi yang telah ditambahkan 1 tetes sampai dengan 3 tetes indikator pp dititrasi dengan larutan $\mathrm{NaOH} \quad 0,1 \mathrm{M}$ yang telah distandarisasi dengan larutan asam oksalat. Total asam laktat dihitung dengan menggunakan Persamaan 1.

$$
\begin{aligned}
& X=\frac{V_{1} x M \times B M}{V_{2}} \\
& \text { keterangan: } \\
& \mathrm{X} \quad=\text { Kadar asam laktat }(\mathrm{g} / \mathrm{L})
\end{aligned}
$$

$$
\begin{array}{ll}
V_{1} & =\text { Volume larutan } \mathrm{NaOH} \text { untuk } \\
& \text { titrasi }(\mathrm{mL}) \\
\mathrm{M} & =\text { Molaritas larutan } \mathrm{NaOH}(\mathrm{M}) \\
V_{2} & =\text { Volume filtrat yang dititrasi }(\mathrm{mL})
\end{array}
$$

\section{HASIL DAN PEMBAHASAN}

\section{Perlakuan awal kulit buah kakao}

Komposisi kimia kulit buah kakao tercantum dalam Tabel 1. Pada penelitian ini diperoleh data bahwa kadar selulosa dan hemiselulosa kulit buah kakao lebih kecil dari hasil penelitian Daud et al. (2013), namun kadar lignin jauh lebih besar. Tanaman kakao yang tumbuh di Asia termasuk Malaysia dan Indonesia adalah species Trinitario. Perbedaan komposisi kimia disebabkan oleh perbedaan habitat tanaman kakao, dimana pada penelitian ini tanaman kakao berasal dari Daerah Tangkisan, Kulonprogo, DIY, Indonesia, sedangkan pada penelitian Daud et al. (2013) tanaman kakao berasal dari Pusat Pembangunan Komoditi, Parit Botak, Jabatan Pertanian Malaysia. Secara umum, semua dinding sel tumbuhan terutama tersusun atas polimer berbasis gula (karbohidrat) yang terikat pada lignin dengan sejumlah kecil ekstraktif, protein amilum dan anorganik. Komposisi kimia bahan tumbuhan berbeda tergantung pada lokasi geografis, iklim, umur dan komposisi tanah, bahkan komposisi bagian-bagian tumbuhan yang berasalah dari satu tumbuhan yang sama dapat berbeda (Daud et al. 2013).

Studi morfologi permukaan suatu bahan dipelajari dengan menggunakan SEM. SEM diperlukan untuk mengetahui distribusi dan susunan serat dari kulit buah kakao pada berbagai tingkat perbesaran seperti ditunjukkan pada Gambar 1. Permukaan kulit buah kakao tersusun atas partikel berbentuk lamela dan memiliki susunan fibril linier. Susunan yang rapat menunjukkan kulit buah kakao memiliki kadar lignoselulosa yang tinggi (a). Lamela ini tersusun atas serat-serat yang menyebabkan lapisan permukaan kulit buah kakao menjadi tebal dan kasar (b). Lapisan yang tebal dan kasar berfungsi untuk melindungi kandungan lignoselulosa di dalam serat. Permukaan kulit buah kakao merupakan partikel yang tidak seragam yang menunjukkan lignoselulosa tersusun atas berbagai senyawa yaitu lignin, selulosa dan hemiselulosa, dan terdapat juga zat eksraktif lain seperti pektin dan polifenol (Daud et al. 2013). 
Tabel 1. Perbandingan komposisi kimia kulit buah kakao

\begin{tabular}{lcc}
\hline Komponen & $\begin{array}{c}\text { Kulit buah kakao } \\
\text { penelitian ini }\end{array}$ & $\begin{array}{c}\text { Kulit buah kakao } \\
\text { Daud et al. 2013 }\end{array}$ \\
\hline Hemiselulosa(\%) & 23,36 & 37,0 \\
Selulosa(\%) & 24,51 & 35,4 \\
Lignin(\%) & 30,46 & 14,7 \\
\hline
\end{tabular}

\section{Delignifikasi}

Hubungan antara pengaruh berbagai kadar $\mathrm{NaOH}$ terhadap kadar lignin, selulosa dan hemiselulosa kulit buah kakao disajikan dalam Gambar 2. Hasil penelitian menunjukkan bahwa pengaruh kadar $\mathrm{NaOH}$ terhadap komposisi kimia kulit buah kakao adalah semakin tinggi kadar $\mathrm{NaOH}$ semakin menurunkan kadar lignin dan hemiselulosa dan semakin menaikkan kadar selulosa. Kadar optimal $\mathrm{NaOH}$ untuk proses delignifikasi kulit buah kakao adalah $6 \%$, yang mampu mengurangi kadar lignin dari $30,46 \%$ menjadi $24,64 \%$ dan hemiselulosa dari $23,36 \%$ menjadi $14,21 \%$. dengan presentase penurunan masing-masing sebesar $19,11 \%$ dan kadar 39,17\%. Gunam et al. (2011) telah melakukan delignifikasi ampas tebu dengan larutan $\mathrm{NaOH}$ yang mendapatkan kadar $\mathrm{NaOH}$ optimal adalah $6 \%$ dengan presentase penurunan lignin dan hemiselulosa masingmasing $32,11 \%$ dan $42,87 \%$.

Persentase penurunan kadar lignin pada ampas tebu lebih besar daripada kulit buah kakao, sedangkan penurunan kadar hemiselulosa relatif hampir sama. Delignifikasi pada lignoselulosa dengan kadar lignin yang sama, tetapi sumbernya berbeda membutuhkan kadar $\mathrm{NaOH}$ yang berbeda. $\mathrm{NaOH}$ dapat memutus ikatan antara selulosa dan hemiselulosa dengan lignin, juga dapat memutus ikatan di dalam lignin itu sendiri. Ikatan yang terputus adalah ikatan hidrogen yang menghubungkan antara lignin dengan selulosa maupun hemiselulosa serta ikatan antara lignin dan hemiselulosa yang berupa gugus eter maupun ester. $\mathrm{NaOH}$ juga dapat memutus ikatan di dalam senyawa lignin yang terdiri atas gugus eter dan ikatan karbonkarbon menjadi fragmen-fragmen lignin (Lebo et al. 2001). Pemutusan salah satu ikatan antara selulosa dan lignin dideskripsikan pada Gambar 3. Reaksi dengan $\mathrm{NaOH}$ juga menyebabkan putusnya ikatan di dalam senyawa lignin yang menyebabkan molekul lignin terdegradasi. Degradasi lignin diawali oleh penyerangan atom $\mathrm{H}$ yang terikat pada gugus $\mathrm{OH}$ fenolik oleh ion hidroksi $(\mathrm{OH})$ dari $\mathrm{NaOH}$ (Gambar 4). Adanya lignin yang terlarut ditandai dengan larutan yang berwarna hitam pekat. Warna hitam ini timbul sebagai indikasi terlarutnya senyawa-senyawa yang memiliki gugus kromofor yaitu gugus yang memiliki ikatan rangkap terkonjugasi yang menyebabkan suatu senyawa dapat menyerap cahaya dengan panjang gelombang $200 \mathrm{~nm}$ sampai dengan $400 \mathrm{~nm}$ (UV).

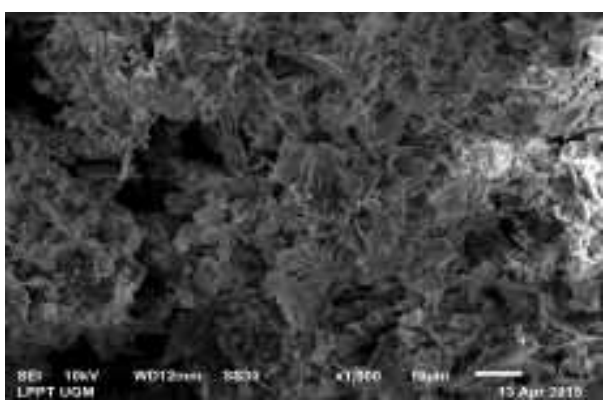

(a)

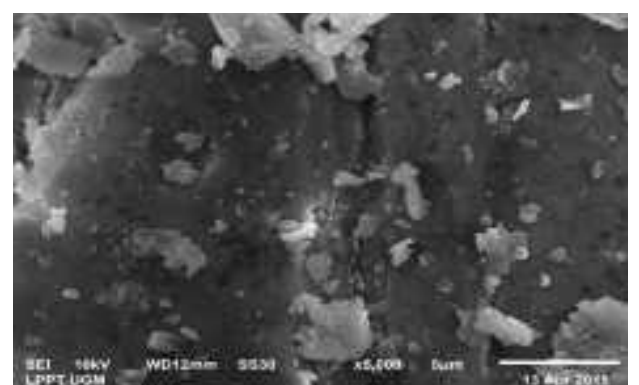

(b)

Gambar 1. Profil SEM kulit buah kakao a) perbesaran 1000x, b) perbesaran 5000x
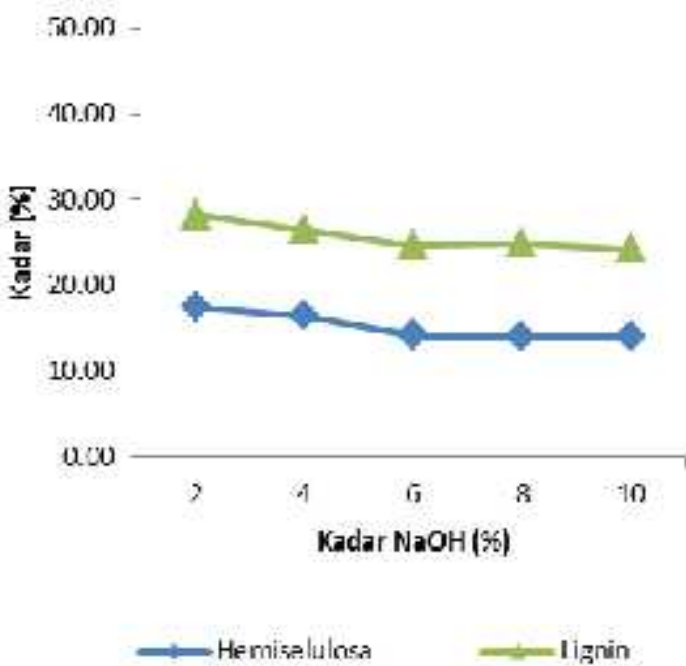

Gambar 2. Pengaruh kadar $\mathrm{NaOH}$ terhadap komposisi kimia kulit buah kakao 
Proses delignifikasi juga dapat mengurangi kadar hemiselulosa karena hemiselulosa lebih mudah larut dalam basa. Molekul hemiselulosa yang larut adalah molekul rantai pendek dan rantai cabang serta terjadinya asetilasi pada gugus substituen hemiselulosa, sedangkan ikatan glikosidik intramolekul hemiselulosa sulit dipecahkan (Peng et al. 2012)

\section{Hidrolisis Asam}

Reaksi hidrolisis selulosa dengan katalis asam secara umum digambarkan pada Gambar 5.

Pengaruh konsentrasi asam, suhu dan waktu terhadap hidrolisis asam disajikan berturut-turut pada Gambar 6, Gambar 7 dan
Gambar 8. Hubungan antara konsentrasi asam dengan kadar glukosa hasil hidrolisis adalah semakin tinggi konsentrasi $\mathrm{H}_{2} \mathrm{SO}_{4}$ maka semakin tinggi pula kadar glukosa yang dihasilkan hingga mencapai optimum pada konsentrasi $\mathrm{H}_{2} \mathrm{SO}_{4} 2,0 \%$. Hal ini menunjukkan bahwa aktivitas katalitik sebanding dengan konsentrasi $\mathrm{H}^{+}$. Semakin banyak ion hidrogen di dalam larutan, maka reaksi hidrolisis yang terjadi akan semakin cepat, pemutusan ikatan glikosidik semakin meningkat dan glukosa yang terbentuk akibat degradasi selulosa semakin banyak. Hemiselulosa dapat terdegradasi menjadi glukosa maupun xylosa, namun pada penelitian ini xylosa yang terbentuk tidak diamati (Laopaiboon 2010).

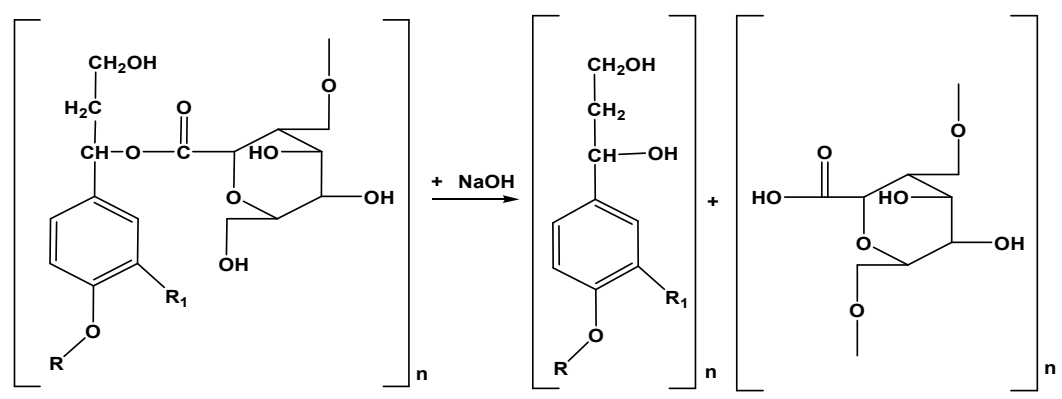

Gambar 3 Reaksi pemutusan ikatan lignin dengan selulosa (Fengel dan Wegener 1995)

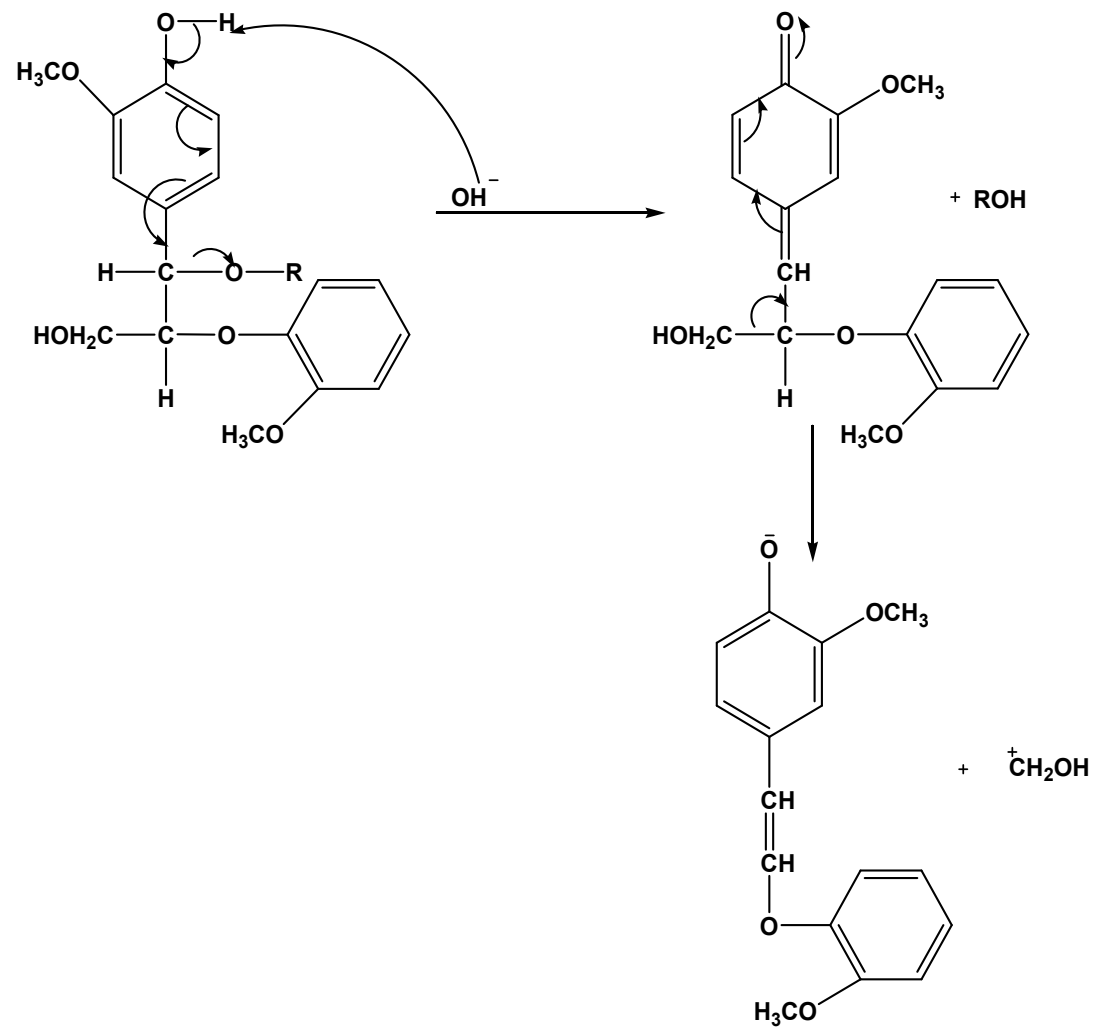

Gambar 4. Mekanisme degradasi lignin 

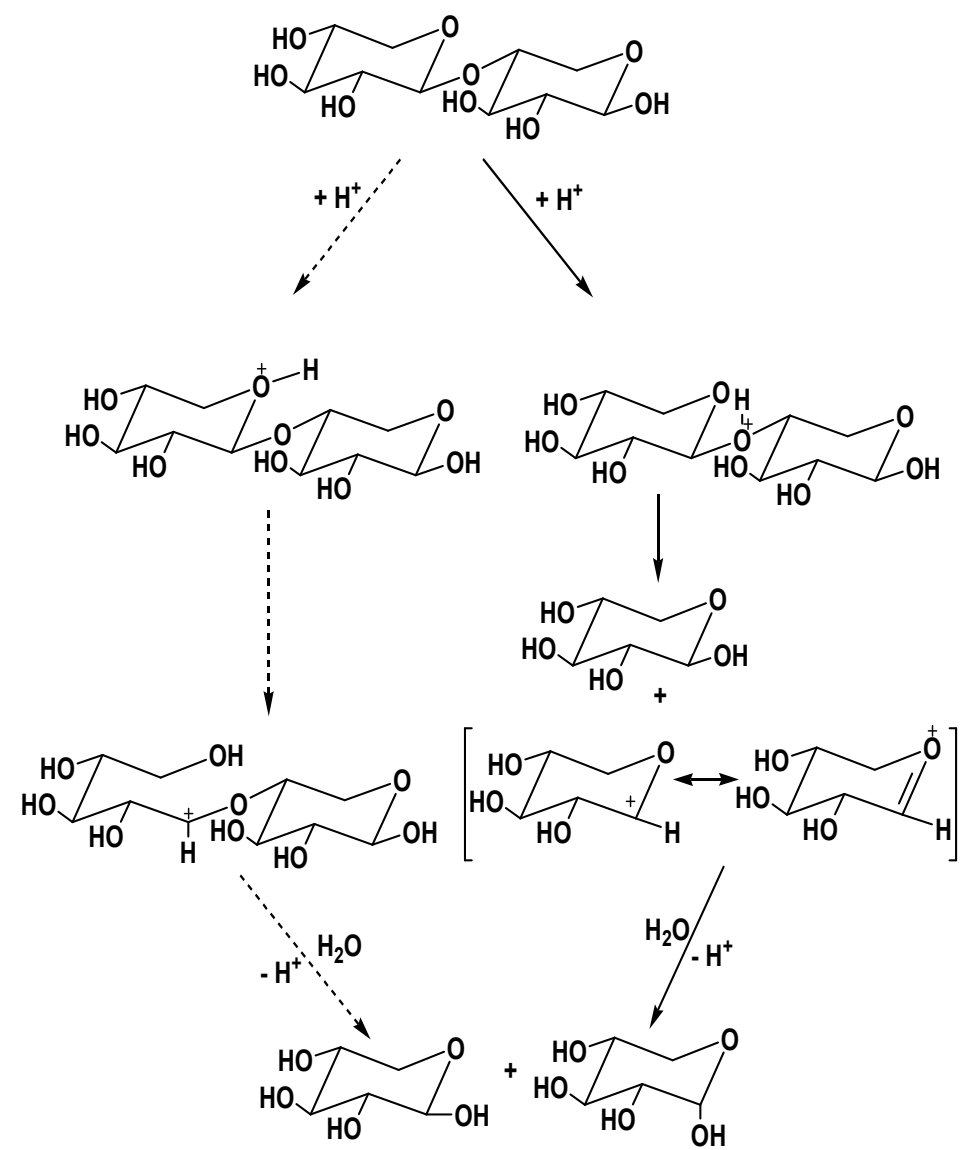

Gambar 5. Reaksi hidrolisis selulosa dengan katalis asam (Xiang et al. 2003)

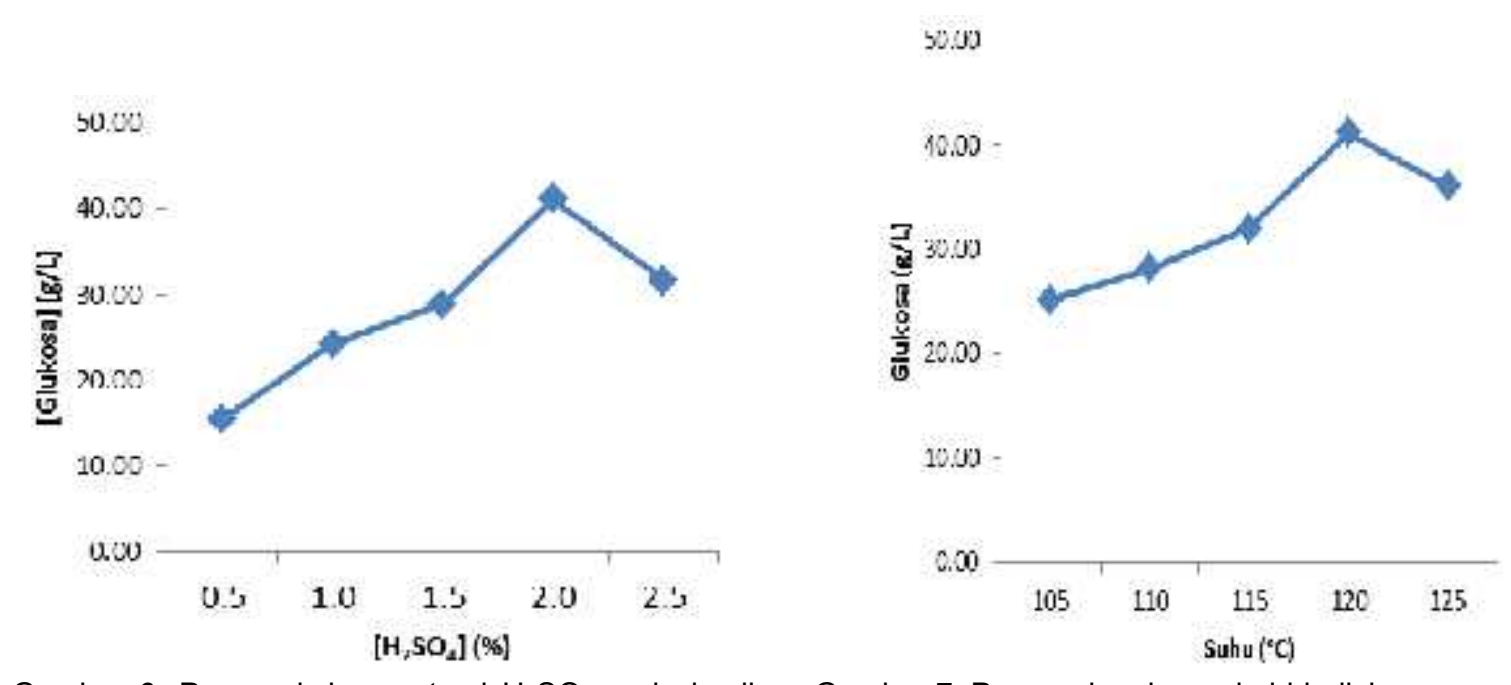

Gambar 6. Pengaruh konsentrasi $\mathrm{H}_{2} \mathrm{SO}_{4}$ pada hasil Gambar 7. Pengaruh suhu pada hidrolisis asam hidrolisis asam 


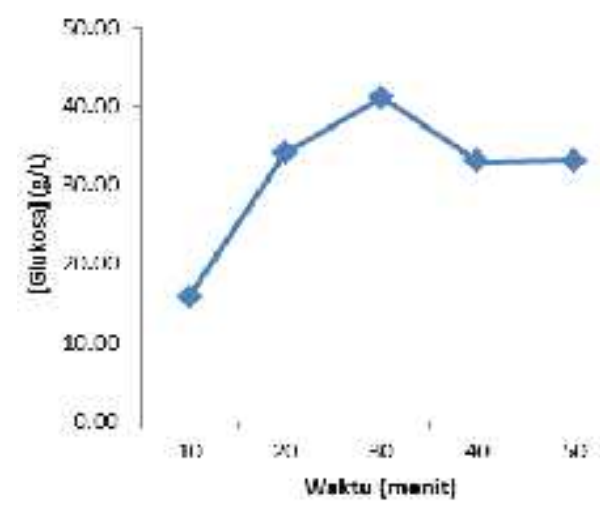

Gambar 8. Pengaruh waktu reaksi hidrolisis

Kenaikan suhu mengakibatkan kenaikan glukosa hasil hidrolisis. Proses hidrolisis pada suhu $120^{\circ} \mathrm{C}$ menghasilkan kadar glukosa tertinggi dan terendah pada suhu $105^{\circ} \mathrm{C}$. Kenaikan kadar glukosa hasil hidrolisis akibat kenaikan temperatur ini sesuai dengan persamaan Arrhenius $k=A \cdot e^{-E a / R T}$ yang menunjukkan semakin tinggi temperatur, nilai konstanta laju reaksi hidrolisa akan semakin besar (Xiang et al. 2003). Pengaruh waktu reaksi terhadap hidrolisis asam menunjukkan bahwa semakin lama waktu reaksi mengakibatkan kenaikan glukosa hasil hidrolisis, namun menurun setelah mencapai optimum. Kadar glukosa optimum dicapai pada waktu hidrolisis 30 menit, pada waktu 40 menit dan 50 menit terjadi penurunan kadar glukosa. Pada waktu reaksi yang lebih lama, konsentrasi asam yang tinggi dan suhu lebih dari $55^{\circ} \mathrm{C}$ dapat terjadi deformasi glukosa menjadi hidroksi metil furfural dan xylosa menjadi furfural (Laopaiboon 2010). Produk samping lain yang mungkin terbentuk adalah asam asetat dan asam format. Asam asetat terutama dapat terbentuk dari degradasi hemiselulosa glucorooxylan. Asam format bisa terbentuk akibat degradasi furfural dan hidroksi metil furfural (Lee et al. 2011).

Hasil optimasi proses hidrolisis asam menunjukkan bahwa kondisi optimum hidrolisis adalah konsentrasi asam sulfat $2 \%$, suhu $120^{\circ} \mathrm{C}$ dan waktu 30 menit. Hasil analisa komponen LCM kulit buah kakao sebelum dan setelah proses hidrolisis ditunjukkan pada Tabel 2. Data ini menunjukkan bahwa proses hidrolisis yang dilakukan dapat memecah sebagian besar hemiselulosa dan sedikit selulosa. Selulosa kristalin lebih stabil daripada selulosa yang berstruktur amorf sehingga sulit terhidrolisis. Hemiselulosa lebih mudah terhidrolisis menjadi komponen penyusunnya seperti pentosa (xylosa, arabinosa), heksosa (mannosa, glukosa, galaktosa), dan gula asam (asam glukoronat dan asam galakturonat) karena struktur hemiselulosa berupa rantai cabang dan bersifat amorf (Taherzadh dan Karimi 2007). Lignin cenderung lebih stabil terhadap asam.

\section{Karakterisasi dengan spektrofotometer IR}

Karakterisasi dengan FTIR bertujuan untuk mengetahui gugus-gugus fungsional yang terdapat dalam serbuk kulit buah kakao (Kakao), kulit buah kakao terdelignifikasi (Kakao-D) dan kulit buah kakao setelah proses hidrolisis asam (Kakao-H). Spektra IR ketiga bahan tersebut disajikan pada Gambar 9 .

Berdasarkan spektra infra merah kakao yang dihasilkan, pita serapan lignin terdapat pada 1620, $21 \mathrm{~cm}^{-1}$ dan 1519,91 $\mathrm{cm}^{-1}$ yang menunjukkan serapan gugus $\mathrm{C}=\mathrm{C}$ ulur dari cincin aromatik, serapan gugus $\mathrm{C}-\mathrm{O}$ fenolik pada daerah $1219,01 \mathrm{~cm}^{-1}$ dan serapan gugus $\mathrm{OH}$ pada daerah $3410,15 \mathrm{~cm}^{-1}$. Pita serapan selulosa ditunjukkan oleh adanya serapan gugus C-H sp ${ }^{3}$ tekuk pada daerah $2924,09 \mathrm{~cm}^{-1}$ dan $1381,03 \mathrm{~cm}^{-1}$, serapan gugus $\mathrm{CH}_{2}$ kibasan pada daerah $1319,31 \mathrm{~cm}^{-1}$, serapan gugus COC asimetri pada daerah $1055,99 \mathrm{~cm}^{-1}$ dan serapan cincin asimetri keluar bidang pada daerah $894,97 \mathrm{~cm}^{-1}$. Serapan gugus CO ulur pada daerah $1257,57 \mathrm{~cm}^{-1}$ berasal dari lignin dan hemiselulosa (Lionetto et al.2015).

Tabel 2. Perbandingan komponen kimia sebelum dan setelah hidrolisis

\begin{tabular}{lccc}
\hline Komponen & $\begin{array}{c}\text { Kulit buah } \\
\text { kakao } \\
\text { awal }\end{array}$ & $\begin{array}{c}\text { Kulit buah } \\
\text { kakao } \\
\text { setelah } \\
\text { delignifikasi }\end{array}$ & $\begin{array}{c}\text { Kulit buah } \\
\text { kakao } \\
\text { setelah } \\
\text { hidrolisis }\end{array}$ \\
\hline Hemiselulosa(\%) & 23,36 & 14,21 & 4,39 \\
Selulosa(\%) & 24,51 & 39,95 & 37,07 \\
Lignin(\%) & 30,46 & 24,64 & 24,08
\end{tabular}

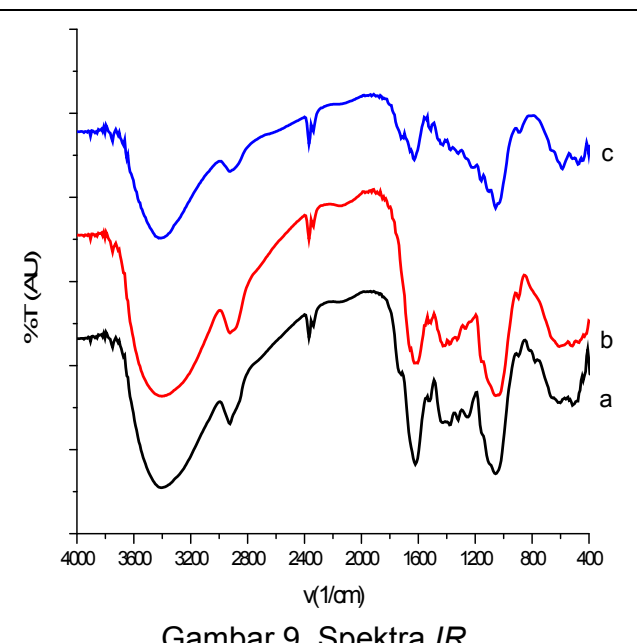

a) Kakao, b) Kakao-D, c) Kakao H 
Spektra IR dari kulit buah kakao terdelignifikasi menunjukkan adanya pergeseran puncak serapan dari beberapa gugus fungsi seperti yang terlihat pada Gambar 6 dan secara lebih detail tertuang pada Tabel 4 antara lain: gugus $\mathrm{OH}$ bergeser dari 3410,15 $\mathrm{cm}^{-1}$ ke $3402,43 \mathrm{~cm}^{-1}$, gugus $\mathrm{C}=\mathrm{C}$ ulur dari $1519,91 \mathrm{~cm}^{-1}$ ke $1512,19 \mathrm{~cm}^{-1}$ dan gugus CO ulur dari $1257,59 \mathrm{~cm}^{-1}$ ke $1265,3 \mathrm{~cm}^{-1}$ yang disebabkan oleh adanya perubahan pada lignin, selulosa dan hemiselulosa. Hal ini didukung data terjadi sedikit penurunan kadar lignin dan hemiselulosa dan kenaikan kadar selulosa.

Proses hidrolisis yang dilakukan pada kulit buah kakao terdelignifikasi juga mengakibatkan terjadinya pergeseran spektra. Serapan gugus $\mathrm{C}-\mathrm{H}$ tekuk bergeser dari $1381,03 \mathrm{~cm}^{-1}$ ke $1373,32 \mathrm{~cm}^{-1}$, serapan dari cincin asimetri keluar bidang bergeser dari $894,97 \mathrm{~cm}^{-1}$ ke $887,26 \mathrm{~cm}^{-1}$ menunjukkan terjadinya perubahan pada selulosa. Hilangnya puncak serapan $\mathrm{CO}$ ulur pada daerah $1265,3 \mathrm{~cm}^{-1}$ menunjukkan terjadinya perubahan signifikan pada hemiselulosa. Hal ini didukung data bahwa proses hidrolisis mengakibatkan sedikit penurunan selulosa dan penurunan hemiselulosa yang signifikan.

\section{Karakterisasi dengan $X R D$}

Karakterisasi dengan $X R D$ bertujuan untuk mengetahui struktur selulosa pada kulit buah kakao karena selulosa tersusun atas struktur amorf dan kristalin. memiliki dua puncak yang spesifik di $2 \theta=15,7^{\circ}$ dan $22,5^{\circ}$ (Rodiansono et al. 2013). Kedua puncak mengindikasikan berturut-turut bagian amorf dan kristalin. Indek kristalinitas dihitung berdasarkan Persamaan 2 yang diajukan oleh Segal et al. (1959) dalam Rodiansono et al. (2013):

$$
X_{C V}=\frac{I_{\text {NI }}-I_{A M}}{I_{A M}}
$$

keterangan:

$$
\begin{aligned}
X_{C R}= & \text { Kristalinitas sampel } \\
\mathrm{I}_{200}= & \text { Intensitas bagian krital selulosa } \\
& \left(2 \theta=22,5^{\circ}\right) \\
\mathrm{I}_{\mathrm{AM}} \quad= & \text { Intensitas bagian amorf selulosa } \\
& \left(2 \theta=15,7^{\circ}\right)
\end{aligned}
$$

\begin{tabular}{|c|c|c|c|c|}
\hline \multicolumn{3}{|c|}{ Bilangan gelombang $\left(\mathrm{cm}^{-1}\right)$} & \multirow[b]{2}{*}{ Gugus Fungsi } & \multirow[b]{2}{*}{ Indikasi } \\
\hline Kakao & Kakao-D & Kakao-H & & \\
\hline 3410,15 & 3402,43 & 3410,15 & Vibrasi ulur gugus $\mathrm{O}-\mathrm{H}$ & Lignin \\
\hline 2924,09 & 2924,09 & 2924,09 & $\mathrm{C}-\mathrm{H} \mathrm{sp}{ }^{3}$ & Selulosa \\
\hline 1620,21 & 1620,21 & 1627,92 & $\mathrm{C}=\mathrm{C}$ ulur cincin aromatik & Lignin \\
\hline 1519,91 & 1512,19 & 1512,19 & $\mathrm{C}=\mathrm{C}$ ulur cincin aromatik & Lignin \\
\hline 1381,03 & 1381,03 & 1373,32 & C-H tekuk & Selulosa \\
\hline 1319,31 & 1327,03 & 1319,31 & $\mathrm{CH}_{2}$ kibasan & Selulosa \\
\hline 1257,59 & 1265,3 & - & CO ulur & $\begin{array}{l}\text { Lignin dan } \\
\text { hemiselulosa }\end{array}$ \\
\hline 1219,01 & 1219,01 & 1219,01 & C-O fenolik & Lignin \\
\hline 1056,99 & 1056,99 & 1056,99 & COC asimetri jembatan oksigen & Selulosa \\
\hline 894,97 & 894,97 & 887,26 & Cincin asimetri keluar bidang & Selulosa \\
\hline
\end{tabular}

Tabel 4. Serapan Infra Merah Serbuk Kulit Buah Kakao 
Pola XRD dari serbuk kulit buah kakao (Kakao), kulit buah kakao terdelignifikasi (KakaoD) dan kulit buah kakao disajikan pada Gambar 10 dan indeks kristalinitas sampel disajikan dalam Tabel 5.

Data menunjukkan terjadi penurunan indeks kristalinitas dari kakao setelah proses delignifikasi dan terjadi peningkatan indeks kristalinitas setelah proses hidrolisis. Kadar lignin dan hemiselulosa yang tinggi pada kulit buah kakao mengakibatkan kulit buah kakao memiliki kristalinitas rendah. Hal ini disebabkan karena lignin dan hemiselulosa berstruktur amorf. Proses delignifikasi hanya dapat melarutkan sedikit lignin dan hemiselulosa, namun delignifikasi dapat sedikit menurunkan kristalinitas sampel. Kenaikan indeks kristalinitas pada kakao-H menunjukkan bahwa hidrolisis hanya dapat memecah sebagian besar hemiselulosa dan sedikit selulosa yang berstruktur amorf, sedangkan selulosa kristalin belum terhidrolisis. Hal ini didukung data kadar selulosa kulit buah kakao hasil hidrolisis masih tinggi.

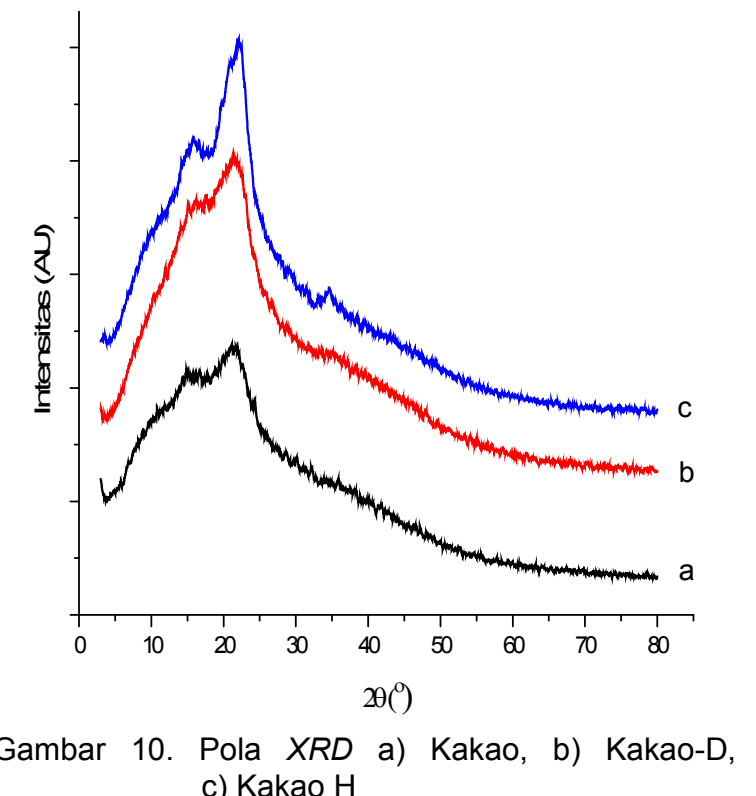

Tabel 5. Indeks kristalinitas

\begin{tabular}{lccc}
\hline Sampel & \multicolumn{1}{l}{$\mathrm{I}_{200}\left(2 \theta=22,5^{\circ}\right)$} & $\begin{array}{l}\mathrm{I}_{\mathrm{AM}} \\
\left(2 \theta=15,7^{\circ}\right)\end{array}$ & $\mathrm{X}_{\mathrm{CR}}(\%)$ \\
Kakao & 70 & 24 & 65,71 \\
Kakao-D & 127 & 46 & 63,78 \\
Kakao-H & 232 & 64 & 72,41 \\
\hline
\end{tabular}

\section{Fermentasi Asam Laktat}

Data hasil fermentasi asam laktat dengan media MRS modifikasi yang mengandung glukosa hasil hidrolisis asam berupa $\mathrm{pH}$ disajikan pada Gambar 11. Penurunan glukosa dan peningkatan total asam laktat disajikan pada Gambar 12. Hasil penelitian menunjukkan bahwa terjadi penurunan $\mathrm{pH}$ dari waktu ke-0 sampai ke-12 kemudian mencapai stabil, seiring dengan penurunan kadar glukosa dan peningkatan kadar asam laktat. Penurunan $\mathrm{pH}$ terjadi dari $\mathrm{pH} 5,3$ dan stabil pada $\mathrm{pH}$ sekitar 4,5 dimana asam laktat yang terbentuk tidak bertambah lagi. $\mathrm{pH}$ optimum pertumbuhan bakteri Lactobacillus plantarum adalah 4,5-6,5 (Pelczar 1988), sehingga pada $\mathrm{pH}$ kurang dari 4,5 aktivitasnya berkurang yang ditunjukkan oleh tidak terjadinya peningkatan kadar asam laktat. Disamping itu, data menunjukkan bahwa aktivitas bakteri L. plantarum optimum pada waktu 12 jam. Hasil ini sejalan dengan data penelitian Indrarti et al. (2005) yang menunjukkan bahwa L. plantarum berada pada fasa log pertumbuhan pada rentang waktu 6-12 jam. Pada waktu selanjutnya $L$. plantarum mengalami fase lag yang ditandai dengan aktivitas yang rendah.

Kadar optimal asam laktat yang terbentuk sebesar 13,27 $\mathrm{g} / \mathrm{L}(1,33 \%)$ dan glukosa yang dikonsumsi sebanyak 11,43 g/L. Fermentasi asam laktat dengan bakteri yang sama pada media MRS menghasilkan asam laktat sebesar 2,95\% (Adesokan 2009). Hasil ini menunjukkan bahwa kualitas media MRS modifikasi dari glukosa hasil hidrolisis kulit buah kakao lebih rendah daripada media MRS. 


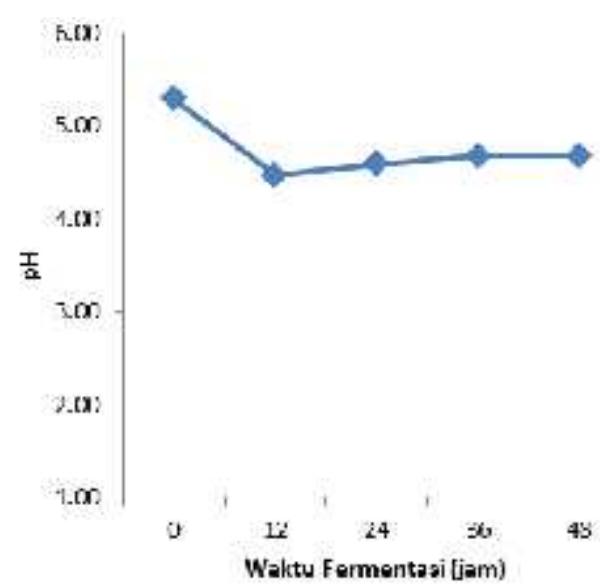

Gambar 11. pH fermentasi asam laktat

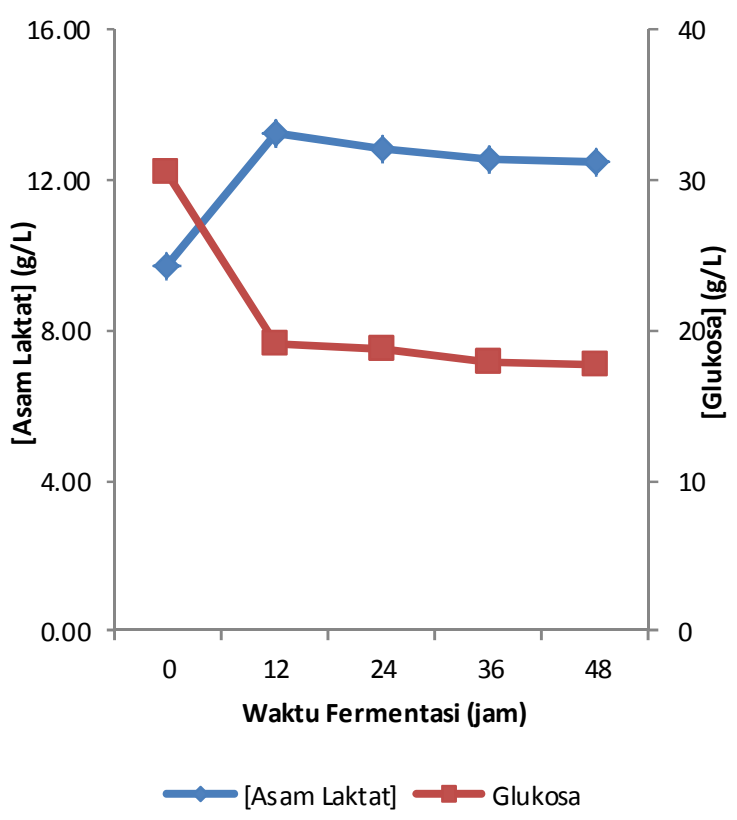

Gambar 12. Kadar glukosa dan total asam laktat

Prosentase kadar asam laktat hasil penelitian ini hampir setara dengan fermentasi terhadap tepung jagung yang menghasilkan asam laktat 2,02\% (Indrarti et al. 2005) dan singkong dengan kadar asam laktat $0,895 \%$ (Pratama et al. 2013). Namun jika dibandingkan dengan hasil fermentasi gula hasil hidrolisis bahan lignoselulosa ampas tebu dengan bakteri Lactobacillus delbreuckii yang menghasilkan $67,0 \mathrm{~g} / \mathrm{L}$ asam laktat (Adsul et al. 2007) maupun limbah tongkol jagung menggunakan bakteri $L$. plantarum dengan kadar asam laktat 73,2 g/L (Okano et al. 2009), maka asam laktat yang dihasilkan dalam penelitian ini sangat kecil. Hal ini dapat terjadi dimungkinkan karena masih adanya senyawa inhibitor dalam media fermentasi. Senyawa inhibitor berupa produk samping hidrolisis asam seperti asam asetat, furfural dan hidroksi metil furfural dapat mengganggu pertumbuhan mikroba karena dapat memasuki membran sel dan menurunkan $\mathrm{pH}$ antar sel sehingga mempengaruhi metabolisme mikroorganisme (Chong et al. 2004). Hal ini mengakibatkan bakteri L. plantarum terhambat pertumbuhannya sehingga asam laktat yang dihasilkan sedikit.

\section{KESIMPULAN}

Konsentrasi optimum $\mathrm{NaOH}$ pada delignifikasi kulit buah kakao adalah $6 \%$, sedangkan kondisi optimum hidrolisis asam adalah konsentrasi $\mathrm{H}_{2} \mathrm{SO}_{4} 2,0 \%$, suhu $120^{\circ} \mathrm{C}$ dan waktu 30 menit. Hidrolisis asam pada penelitian ini hanya dapat memecah hemiselulosa dan selulosa amorf menjadi monomernya, selulosa kristalin cenderung lebih stabil. Glukosa hasil hidrolisis asam digunakan sebagai media fermentasi dan menghasilkan asam laktat sebesar 13,27 $\mathrm{g} / \mathrm{L}$, namun memerlukan proses detoksifikasi untuk menghilangkan senyawa inhibitor yang dapat menghambat proses fermentasi. Disamping itu, perlu dilakukan optimasi proses fermentasi untuk meningkatkan kadar asam laktat yang dihasilkan. Penelitian ini membuka peluang untuk peningkatan nilai tambah kulit buah kakao dan penelitian awal menuju sintesis poli asam laktat yang diperlukan dalam pembuatan plastik biodegradable.

\section{UCAPAN TERIMA KASIH}

Penulis mengucapkan terima kasih kepada Pusat Pendidikan dan Pelatihan Industri yang telah memberikan biaya penelitian dan Balai Besar Kulit Karet dan Plastik atas pemberian ijin penggunaan fasilitas laboratorium selama penelitian.

\section{DAFTAR PUSTAKA}

Adesokan, I.A., B.B. Odetoyinbo, and B.M. Okanlawon. 2009. Optimization of lactic acid production by lactic acid bacteria isolated from some traditional fermented food in nigeria. Pakistan journal of nutrition 8(5): 611-615.

Adsul, M.G., A.J.Varma, and D.V. Gokhale. 2007. Lactic acid production from waste sugarcane bagasse derived cellulose. green chemistry 9: 58-62

Albalasmeh, A.A., A.A. Berhe, and T.A.Ghezzehei. 2013. A New method for rapid determination of carbohydrate 
and total carbon concentrations using uv spectrophotometry. Carbohydrate polymer 97: 253- 261.

Alemawor, F., V.P. Dzogbefia, E.O.K.Oddoye, and J.H. Oldham. 2009. Effects of pleurotus ostreatus fermentation of cocoa pod husk composition: influence of fermentation period and $\mathrm{mn}^{2+}$ supplementation on the fermentation process. African journal of biotechnology 8(9): 1950-1958.

Cruz, G., M. Pirilä, M. Huuhtanen, L.Carrión, E. Alvarenga, and R.L. Keiski. 2012. Production of activated carbon from cocoa (theobroma cacao) pod husk. Journal of civil environment engineering 2(2): 1-6.

Daud Z., A.S.M. Kassim, A.M. Aripin, H. Awang, and M.Z.M. Hatta. 2013. Chemical composition and morphological of cocoa pod husks and cassava peels for pulp and paper production. Australian journal of basic applied science 7(9): 406-411.

Fengel, D. and G. Wegener. 1983. Kayu: kimia, ultrastruktur, reaksi-reaksi. terjemahan Sastrohamidjojo, H. 1995. Yogyakarta: Gadjah Mada University Press.

Gunam,I.B.W., N.M. Wartini, A.A.M.D. Anggraeni, dan P.M.Suparyana. 2011. Delignifikasi ampas tebu dengan larutan natrium hidroksida sebelum proses sakarifikasi secara enzimatis menggunakan enzim selulase kasar dari aspergillus niger FNU 6018. Jurnal teknologi indonesia 34: 24-32.

Hofvendahl, K. and B. Hahn-Hagerdal. 2000. Factor afftecting the fermentative lactic acid production from renewable resources. Enzyme microbial technology 26:87-107.

Indrarti, L., E. Rahimi dan Tati. 2005. Biosintesis asam laktat sebagai bahan baku plastik biodegradabel. Dalam: Prosiding simposium polimer nasional $\checkmark$.

Laopaiboon, P., A. Thani, V. Leelavatcharamas, and L.Laopaiboon. 2010. Acid hydrolysis of sugarcane bagasse for lactic acid production. Bioresource technology 101: 1036-1043.

Lee, J. M., R.A. Venditti, H. Jameel, and W.R. Kenealy. 2011. Detoxification of woody hydrolyzates with activated carbon for bioconversion to ethanol by the thermophilic anaerobic bacterium thremoanaerobacterium saccharolyticum. Biomass and bioenergy 35: 626-636.

Lebo, S. E., J.D. Gargulak, and T.J. McNally. 2001. Kignin. Kirk-Othmer encyclopedia of chemical techmology. USA: John Wiley and sons, Inc.

Lionetto, F., R. Del Sole, D. Cannoletta, G. Vasapollo, and A. Maffezolli. 2012. Monitoring wood degradation during weathering by cellulose crystallinity. Materials 5: 1910-1922.

Nisa, D. dan W.D.R. Putri. 2014. Pemanfaatan selulosa dari kulit buah kakao (theobroma cacao I.) sebagai bahan baku pembuatan carboxymethyl cellulose (CMC). Jurnal pangan dan agro 2(3):34-42

Okano, K., Q. Zhang, S. Shinkawa, S. Yoshida, T. Tanaka, H. Fukuda, and A. Kondo. 2009. Efficient production of optically pure d-lactic acid from raw corn starch by using a genetically modified I-lactate dehydrogenase gene-deficient and $\alpha$ amylase-secreting lactobacillus plantarum strain. Applied environmental microbiology 75(2): 462-467.

Pelczar, C. 1988. Dasar-dasar Mikrobiologi 2. Jakarta: UI Press.

Peng, F., P. Peng., F. Xu and R.C. Dan Sun. 2012. Fractional purification and bioconversion of hemicellulose. Biotechnol. Adv. 30: 879-903

Pratama, A.Y., R.N. Febriani dan S.Gunawa. 2013. Pengaruh ragi roti, ragi tempe, dan lactobacillus plantarum terhadap total asam laktat dan ph pada fermentasi singkong. Jurnal teknik pomits 2(1):90-92.

Pratiwi, P.Eka, M. Yatim, dan L. Edahwati. 2010, Pemanfaatan kulit buah cokelat sebagai bioetanol. Dalam: Prosiding seminar nasional teknik kimia Soebardjo Brotohardjono IX.

Puastuti, W dan Susana IWR. 2014. Potensi dan Pemanfaatan kulit buah kakao sebagai pakan alternatif ternak ruminansia. WARTAZOA 24(3):151-159.

Rahman, M.A.A., Y. Tashiro, and K. Sonomoto. 2011. Lactic acid production from lignosellulosic-derived sugars using lactic acid bacteria: overview and limits: review. Journal of biotechnology 156 (4): 286-301.

Rahman, M.A.A., Y. Tashiro and K. Sonomoto. 2013. Recent advances in lactic acid production by microbial fermentation 
process: Review. Biotechnology advance 31(6): 877-902.

Rodiansono, U.B.L. Utami, N. Widyastuti, P.C. Wulandari, dan I. Risnawati. 2013. Hidrolisis lignoselulosa dari tandan kosong kelapa sawit menggunakan katalis asam karboksilat. Sains dan terapan kimia 7(1): 60-71.

Chong, A.R., J.A. Ramírez, G. Garrote and M. Vázquez. 2004. Hydrolysis of sugarcane bagasse using nitric acid: a kinetic assessment. J. Food Eng. 61(2): 143-152.
Taherzadeh, M. J. and K. Karimi. 2007. Enzymebased hydrolysis processes for ethanol from lignocellulosic material a review. Bioresource 2(4): 707-738.

Wijaya, M.M. 2014. Pemanfaatan limbah kakao sebagai bahan baku produk pangan. Dalam: Prosiding seminar nasional kimia dan pendidikan kimia VI UNS, Surakarta.

Xiang, Q., Y.Y. Lee, P.O. Pettersson, and R.W. Torget. 2003. Heterogeneous aspects of acid hydrolysis of a cellulose. Applied biochemistry and biotechnology :105-108. 